


The World Food Programme encourages local, innovative food solutions, such as Wawa Mum, a fortified chickpea paste developed and produced in Pakistan.

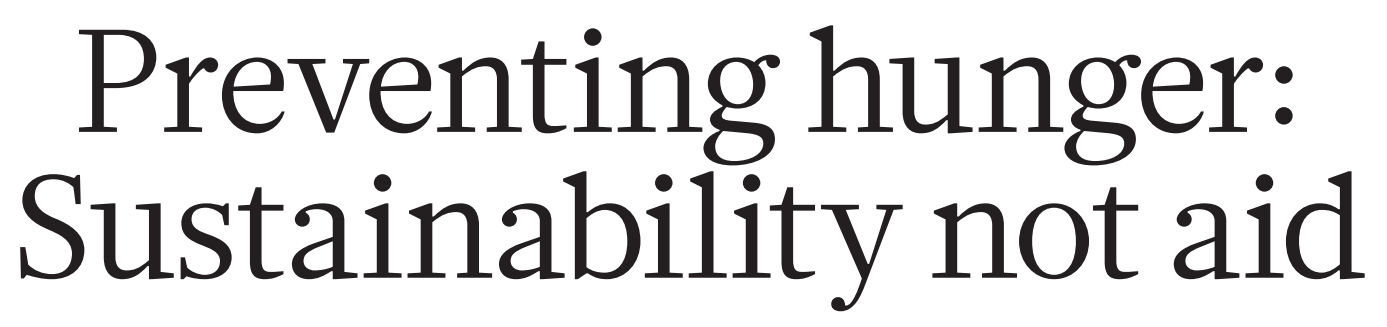

Fifty years after its founding, UN World Food Programme head Josette Sheeran explains why the agency is now focusing on projects that help communities weather food crises.

$\mathrm{N}$ ever before has food been so abundant. Global agriculture produces an estimated $17 \%$ more calories per person than it did 30 years ago, despite a population increase of more than $50 \%$. Yet each morning, nearly 1 billion people wake up hungry, most of them women and children. Although gains have been made in reducing the global population of those undernourished - from about 26\% in 1971 to $13 \%$ in 2008 - the current global economic crisis has pushed millions more into poverty and swelled the ranks of the hungry.

Fifty years ago, in December 1961, the General Assembly of the United Nations approved a resolution that established the World Food Programme (WFP). It was given the goal of saving lives and livelihoods
- bringing food from lands of plenty in the post-war years to those in need. Within a year of its founding, the WFP would undertake three major operations - supplying food for survivors of the disastrous 1962 earthquake in Iran, victims of a typhoon in Thailand and refugees returning to newly independent Algeria. Since then, the WFP has continued to respond to emergencies 
$\checkmark$ around the globe and is now recognized as the world's largest humanitarian organization. Last year alone, it brought food and nutrition support to more than 109 million hungry people in 75 countries.

Food aid has saved millions of lives, but it cannot, by itself, solve hunger. This is why, over the past few years, the WFP has been undergoing one of the most profound transformations in its history, as it moves from a food-aid agency to one that helps individuals, communities and nations to build sustainable food security. In this way its response is smarter, more targeted, and it is able to help the most vulnerable people prepare to withstand shocks - whether from natural disaster, economic crises or food price volatility.

Just as the WFP has evolved since its founding, so too has the environment in which it operates. The difficulties of ensuring access to nutritious food for the most vulnerable people have been compounded by a convergence of global trends: continued food price volatility; an increase in the number and intensity of weather-related disasters; and an escalation of ongoing conflicts.

\section{ROOT CAUSES}

In 2007 and 2008, when global food and fuel prices skyrocketed and sparked food riots in 35 countries, more than 115 million people were added to the ranks of the hungry. Food prices are again surging on global markets. The World Bank estimates that as a result of these price rises, another 44 million people were pushed into extreme poverty between June 2010 and February 2011. It is those who are extremely poor and vulnerable who suffer the most - women and girls often have disproportionately less food during economic shocks. Families are forced to sacrifice tomorrow for today - eating income-producing livestock, putting schoolchildren to work and switching from more expensive, nutritious food to cheaper staples.

Climatic changes have increased both the frequency and the intensity of natural disasters. Floods and droughts that were once occasional have now become epic and more regular. The 2011 drought in the Horn of Africa was declared the worst in 60 years. The 2010 monsoon floods in Pakistan were the worst in the country's recorded history.

And escalating conflict and political instability have plunged millions around the world into food insecurity. Nowhere have we seen this play out more dramatically than in the Horn of Africa, where Somalis have endured two decades of civil war and two consecutive seasons of failed rains. Now, after their livestock and crops have died, they are faced with the terrible choice left to people without food: migrate or die.

Make no mistake; this is not the failure of aid - but the lack of access to aid.

Although we cannot prevent drought, we can prevent famine. There are hopeful signs that outside Somalia, where those in control have blocked humanitarian assistance, the drought's impact has been blunted by advance preparation and putting in place programmes that help the most vulnerable populations to better weather such crises.

Through the Managing Environmental Resources to Enable Transitions to More Sustainable Livelihoods (MERET) programme, the WFP has been supporting the Ethiopian government in sustainable land management and rain catchment, which has vastly increased food production and mitigated the impact of the drought. In the dry Karamoja region in Uganda, local communities have established a system of communal food stocks that are replenished at harvest time, enabling them to cope with periods of food insecurity.

The WFP is working with countries across the globe at the grass-roots level to develop and scale up - innovative ideas and tools to transform the fight against hunger. In Cameroon, for example, where about 2.8 million people are food insecure and the lean season in the north of the country lasts an average of three to four months, every year can be a crisis for the most vulnerable people. To help break the boom-and-bust cycles of hunger,

"Since its founding, the World Food Programme has worked itself out of a job in more than 50 countries." the WFP provides a one-time donation of 10 tonnes of cereal for each community granary and helps to train farmers in food-storage management and financial accounting. Community members can withdraw stocks from the granary during the lean season, and later replenish from their own crops during harvest, paying little interest. The steering committee for each granary uses the revenue collected from interest and sales of commodities to reconstitute stocks and ensure the village's access to affordable food all year round.

Working with food technologists, we are deploying products such as Wawa Mum. This highly fortified chickpea paste, developed and produced in Pakistan, requires no water or cooking, and contains essential micronutrients for young children, who suffer irreversible damage to their minds and bodies if they don't receive sufficient nutrition in the first 1,000 days of life - from conception until they are 24 months old.

The WFP is also using technology to reach the most vulnerable people and support local economies, through 'digital food' such as electronic vouchers delivered to mobile phones. In the Palestinian territories, for example, beneficiaries are able to use an electronic swipe card to purchase nutritious food at local markets. All the products in the programme, such as milk, yogurt and cheese, are produced locally.

These WFP programmes are fundamentally different from food aid that is often brought from the outside. They enhance food security by ensuring that our responses are supporting local markets and farmers, and enabling residents to buy locally produced products that might otherwise be out of reach. Where the digital-food programme is in operation, local dairy farmers have increased production by $30 \%$. Local shops have more customers and higher profits. And people can choose nutritious food for their families in a way that protects their dignity. Because of this innovative approach to promoting food security, the WFP is increasing cost-efficiency and enabling a better analysis of food consumption patterns in real time.

\section{THE TOOLS ARE AT HAND}

As these examples show, ending hunger does not require a major scientific breakthrough such as those that have graced the pages of this journal. Preventing the loss of a generation of children due to malnutrition is, on one level, relatively simple: women and children need access to an adequate amount of nutritious food. For the first time in history we have the scientific knowledge, programmes, tools and policies to defeat hunger but we need global political will. It requires the commitment of national leaders to put in place the right policies and to declare that people will not starve under their watch.

Former Brazilian President Luiz Inácio Lula da Silva made it clear that fighting hunger would be his top priority, stating in his inaugural address that "if at the end of my term every Brazilian person has three meals per day, I will have fulfilled my life's mission". Since 2003, the Fome Zero (Zero Hunger) programme, which focuses on access to food for the poorest and support for small-scale and family farmers, has helped to halve the proportion of hungry people in Brazil. The country was a WFP beneficiary in the 1990s - now it is our ninth-largest donor.

Since its founding, the WFP has worked itself out of a job in more than 50 countries as nations take over programmes such as school feeding and other safety-net projects - a testament to what can be achieved when national leaders, the private sector and civil society come together and collectively declare "not on our watch". We may always need a WFP when unexpected disaster strikes. But 50 years from now it is my dream that no one will wake up hungry and every child will have sufficient nourishment to reach their potential.

Josette Sheeran is the executive director of the United Nations World Food Programme, 00148 Rome, Italy. e-mail:wfpinfo@wfp.org 